\title{
The distribution and timing of tephra deposition at Siple Dome, Antarctica: possible climatic and rheologic implications
}

\author{
Anthony J. GOW, ${ }^{1}$ Debra A. MEESE ${ }^{1,2}$ \\ ${ }^{1}$ US Army Cold Regions Research and Engineering Laboratory, 72 Lyme Road, Hanover, New Hampshire 03755-1290, USA \\ ${ }^{2}$ Climate Change Institute, University of Maine, 303 Bryand Global Sciences Center, Orono, Maine 04469-5790, USA \\ E-mail: debra.meese@maine.edu
}

\begin{abstract}
Approximately 300 volcanic ash and dust layers were observed in the Siple Dome (Antarctica) ice core. Most of this tephra, deposited between 700 and $800 \mathrm{~m}$ depth, consisted primarily of glass shards with varying amounts of crystalline material and groundmass fragments. The pattern of distribution of tephra fallout closely replicates that found in the Byrd ice core, indicative of contemporaneous deposition at both locations. Peak fallout occurred approximately 19500 years ago, based on methane tie points in the Siple Dome and Greenland Ice Sheet Project 2 (GISP2) ice cores. Mount Berlin was identified as a potential source of tephra, although other volcanoes in West and East Antarctica appear to have contributed ash and dust. Ice between 697 and $730 \mathrm{~m}$, in which fine-grained tephra is concentrated, has undergone enhanced thinning compared to ice with a similar concentration of tephra deposited contemporaneously between 1300 and $1540 \mathrm{~m}$ at Byrd. It is speculated that this thinning has occurred in response to dynamic interaction between ice at Siple Dome and the two ice streams flanking it. A dramatic change to a shear fabric appears to be directly related to the higher concentration of volcanic particles in the ice between 700 and $800 \mathrm{~m}$.
\end{abstract}

\section{INTRODUCTION}

Siple Dome, located at $81.65^{\circ} \mathrm{S}, 148.81^{\circ} \mathrm{W}$ in West Antarctica, is situated between Kamb and Bindschadler Ice Streams (former Ice Streams C and D) at an elevation of $621 \mathrm{~m}$. During February 1999 an ice core was successfully drilled to bedrock at $1004 \mathrm{~m}$ at Siple Dome. Following 1 year's relaxation at the drill site, to allow for relief of internal stresses in the ice, the cores were shipped to the US National Ice Core Laboratory (NICL) in Denver, CO, where processing for studies of physical properties, chemistry, isotopic and entrapped-gas composition were undertaken by various institutions. Physical properties processing included light-table examination of the visual stratigraphy, primarily for the purpose of delineating annual-layer structure in conjunction with electrical conductivity measurements (ECM). The use of these two techniques as primary age-dating tools was discontinued at $508 \mathrm{~m}$ (8.2 kyr BP), due to concerns by some observers that ice deeper than this could not be accurately dated. The reasons for these concerns are given by Taylor and others (2004b) who provide a revised timescale, extending from 8.2 to $30 \mathrm{kyr} \mathrm{BP}$, synchronized with the Greenland Ice Sheet Project 2 (GISP2) timescale (Meese and others, 1997) by correlating major features of the Siple Dome methane record with corresponding features in the GISP2 and Greenland Icecore Project (GRIP) methane records (Brook and others, 1999; Blunier and Brook, 2001). The Siple Dome timescale has now been extended by Brook and others (2005) based on correlating records of atmospheric methane and $\delta^{18} \mathrm{O}$ between GISP2 and Siple Dome.

During light-table examination of the Siple Dome cores, two distinctive kinds of bands or layers were observed that appeared essentially identical to the ash and cloudy bands in the Byrd core (Gow and Williamson, 1971). Ash bands, up to $5 \mathrm{~mm}$ thick at Siple Dome, contained particles large enough to be seen with the naked eye (Fig. 1). As at Byrd, these particular debris bands were subsequently identified as volcanic ash layers. Cloudy bands at Siple Dome were also found to contain volcanic particles, though too small to be observed with the unaided eye. The ice surrounding the cloudy bands, though bubbly, remained transparent, whereas the cloudy bands owe their appearance to the scattering of light by the particles they contain.

According to Kyle and others (1981), 'Where an infall mode of formation is inferred the layers are called tephra layers'. However, dust layers could originate as wind-blown material from non-volcanic sources. Nearly all cloudy bands examined in the Siple Dome core were composed of volcanic debris, principally glass shards, indicative of direct fallout from volcanoes.

\section{ANALYTICAL TECHNIQUES}

The techniques applied to volcanic ash and cloudy band samples from Siple Dome were essentially the same as those used on the Byrd tephra samples (Gow and Williamson, 1971). All tools and glass were pre-cleaned in doubledistilled, deionized water. Ice samples containing tephra were partially melted to remove any incidental contamination resulting from handling and sawing the samples, prior to collecting the remaining meltwater in a beaker. Samples of meltwater were then transferred, using a pipette, onto welltype glass slides which were protected with a cover slip. Additional samples were prepared by pipetting several drops of the tephra-layer meltwater directly onto plain glass slides, allowing the water to evaporate and then examining the volcanic residue with a microscope. A Leica Model DMLM microscope with a digital camera was used to determine the overall physical composition of each tephra sample.

\section{PHYSICAL CHARACTERISTICS OF TEPHRA LAYERS}

Microscopic examination of particles from two ash layers and ten cloudy bands revealed that all contained volcanic 


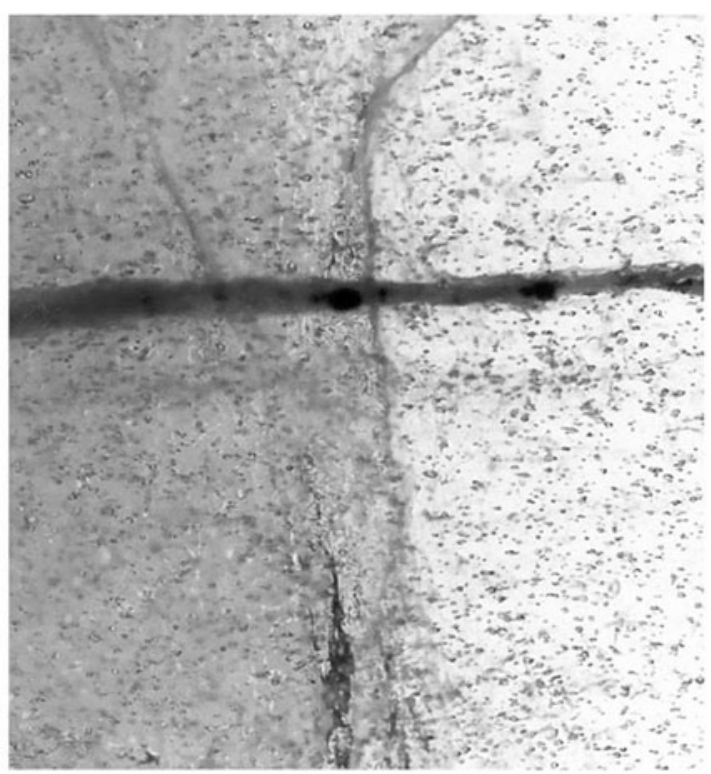

$549.97 \mathrm{~m}$

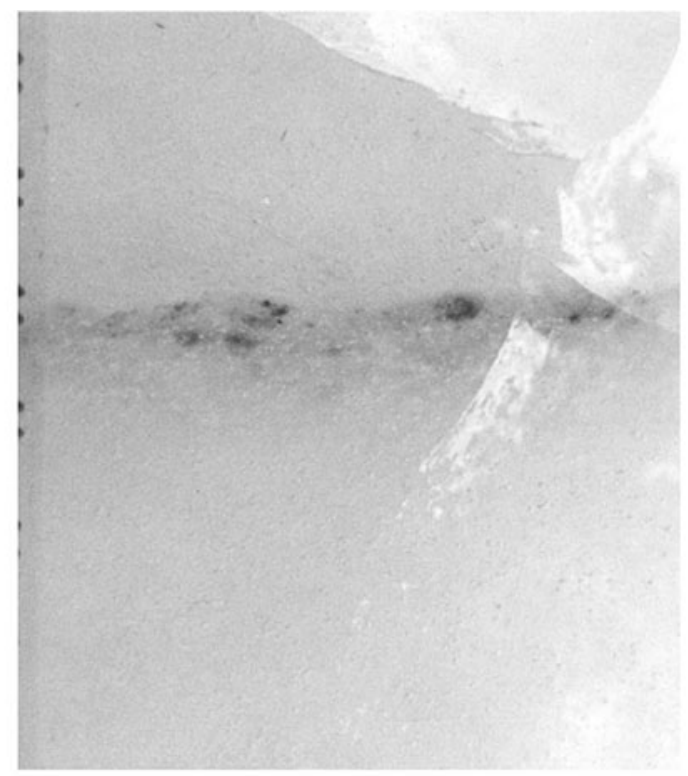

$759.23 \mathrm{~m}$

\section{$10 \mathrm{~mm}$}

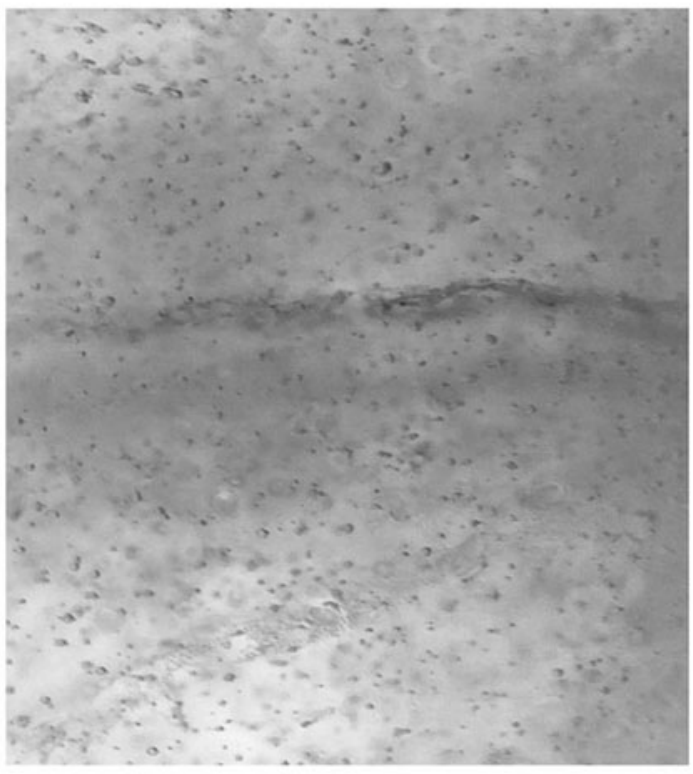

$708.22 \mathrm{~m}$

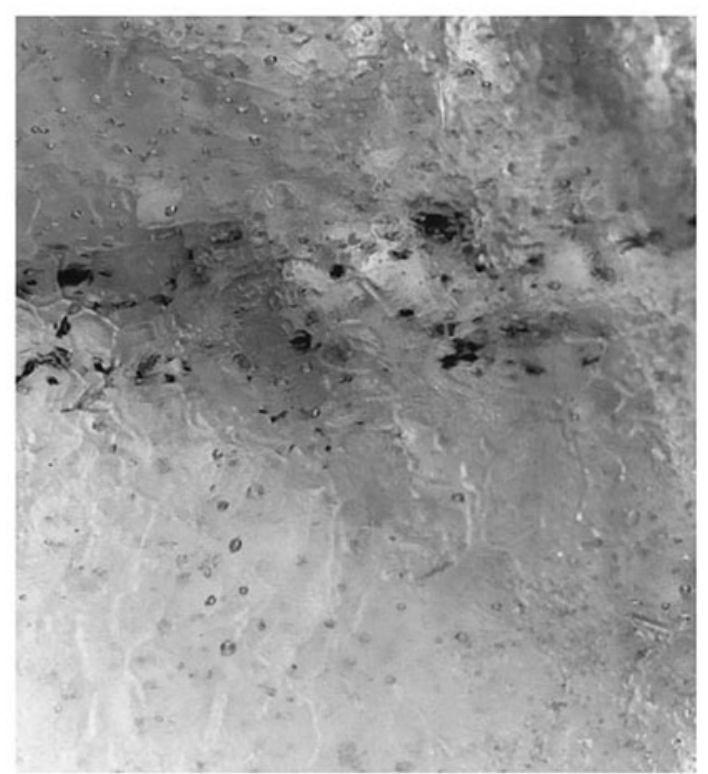

$786.16 \mathrm{~m}$

Fig. 1. Photomicrographs of four ash layers in the Siple Dome ice core.

glass shards with varying amounts of groundmass fragments and other crystalline material. Representative photomicrographs of tephra particles are presented in Figure 2. Ten ash layers were visually identified in Siple Dome cores. Nine of these were at depths greater than $505 \mathrm{~m}$. Both green and brown ash layers were observed. A single ash layer at $549.97 \mathrm{~m}$ appeared to be underlain by a melt layer. The mean particle size was approximately $50 \mu \mathrm{m}$; particles $>100 \mu \mathrm{m}$ in diameter were not uncommon. A very similar particle-size range was observed in ash layers at Byrd. The layers usually occurred as single bands up to $5 \mathrm{~mm}$ thick, occasionally as bifurcated layers (e.g. at $733.33 \mathrm{~m}$ ) or as occasional sets of closely spaced layers (786.14-786.18 m). At Byrd, infalls of ash up to $6 \mathrm{~cm}$ thick were observed, which is much thicker than any ash layer in the Siple Dome core, possibly indicating a more distal source at Siple Dome.

The cloudy bands were concentrated in a zone from 697 to $730 \mathrm{~m}$ depth, and occurred sporadically above and below this zone. In cloudy bands, generally $1-3 \mathrm{~mm}$ thick but up to $10 \mathrm{~mm}$ thick, the particle size was much smaller than the ash, averaging $5 \mu \mathrm{m}$. However the largest particles approached the mean particle size for ash layers $(50 \mu \mathrm{m})$. This variability in particle size of the Siple Dome cloudy bands was appreciably greater than that observed in the Byrd core.

Based on visual inspection, the Siple Dome core contains fewer identifiable tephra layers than the Byrd core. Whereas 25 ash layers and an estimated 2000 volcanic dust layers were observed in the Byrd core, only ten ash layers and 
2300 cloudy bands were visually identified in the Siple Dome core. The reasons for these discrepancies in numbers of visible tephra layers have not been determined; however, the fact that the Siple Dome core has remained extremely brittle and prone to widespread fracturing, unlike the Byrd core, is likely to have made it impossible to accurately determine the number of tephra layers in the Siple Dome core. As discussed later, the pattern of distribution of tephra fallout at Siple Dome closely replicates that in the Byrd core, indicating that deposition of tephra was essentially contemporaneous at the two locations. The occurrence of the bulk of tephra deposition between 700 and $800 \mathrm{~m}$ at Siple Dome confirmed an earlier prediction of Gow and Engelhardt (2000), based on modeled age-depth scales by Nereson and others (1996), that tephra coeval with that in the Byrd core should be concentrated in this region.

\section{CHEMICAL CHARACTERISTICS OF TEPHRA LAYERS}

Chemical analyses of glass shards were conducted on a suite of eight ash layers and five cloudy bands that were selected independently of the 12 tephra layers examined under the microscope. Sample preparation and filtering of tephra particles were performed at the Climate Change Institute, University of Maine, USA, by A. Kurbatov, followed by electron microprobe analyses of glass shards by N. Dunbar at the New Mexico Bureau of Mines and Mineral Resources, Socorro, NM, USA. Results of these analyses are presented in Table 1 together with tephra type and probable volcanic source wherever it could be reasonably determined. Of the 13 tephra layers examined, seven showed peralkaline trachyte affinities, based on microprobe analyses of their glass shards; three displayed more variable glass-shard compositions, indicative of zoned or multiple volcanic events; particles from a single cloudy band exhibited chemical characteristics more typical of a wind-blown non-volcanic deposit; and in two of the five cloudy bands none of the particles examined appeared to be of volcanic origin or, at least, none larger than the $2.5 \mu \mathrm{m}$ size filter used to collect particles at the University of Maine.

Based on the chemical composition of the glass shards, Mount Berlin, West Antarctica, has been identified as the source volcano for two of the ash layers, and two other ash layers were tentatively correlated with eruptions from Mount Takahe, West Antarctica, and Cerro Hudson, Chile. The source volcanoes for the remaining six tephra layers have not, as yet, been positively identified.

\section{COMPARISONS WITH A DOWN-HOLE DUST LOGGER}

An optical dust logger was deployed down-hole to examine ice in the walls of the Siple Dome drillhole (Bay and others, 2001). Details of the design principles and optics of this logger are described by Bay and others (2001). All ten ash bands identified in the core were found to correspond very closely with highly absorbing layers that occur as very sharp spikes on the dust-logger record. Additional highly absorbing layers have been provisionally attributed to ash layers. None of these spikes appear to be associated with the large number of cloudy bands ( $>300)$ that were concentrated in the zone from 698 to $725 \mathrm{~m}$, indicating that the size and concentration of particles in these bands were not sufficient to elicit a diagnostic signal in the dust-logger record.

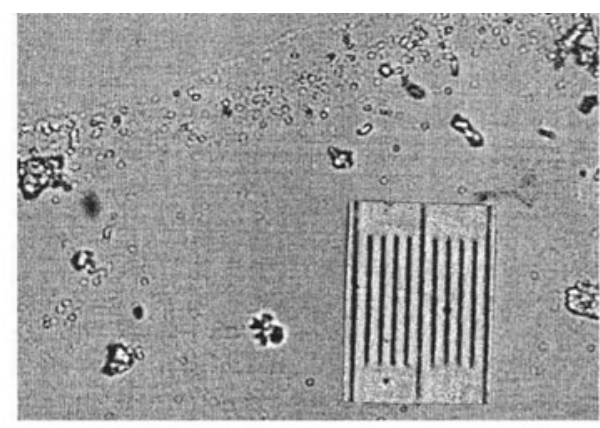

$707.84 \mathrm{~m}$

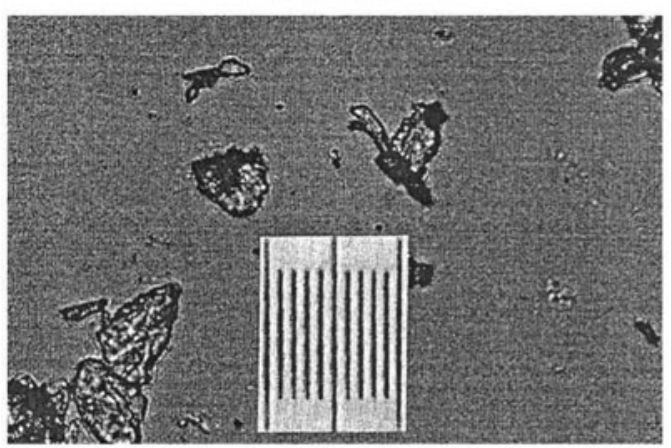

$708.85 \mathrm{~m}$

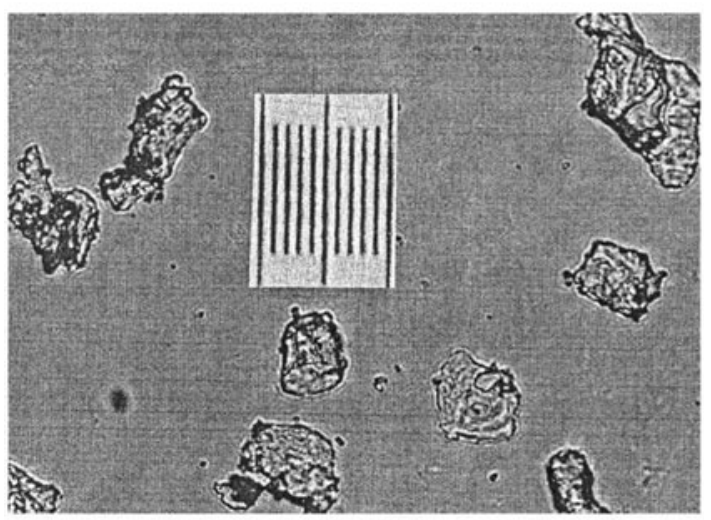

$709.84 \mathrm{~m}$

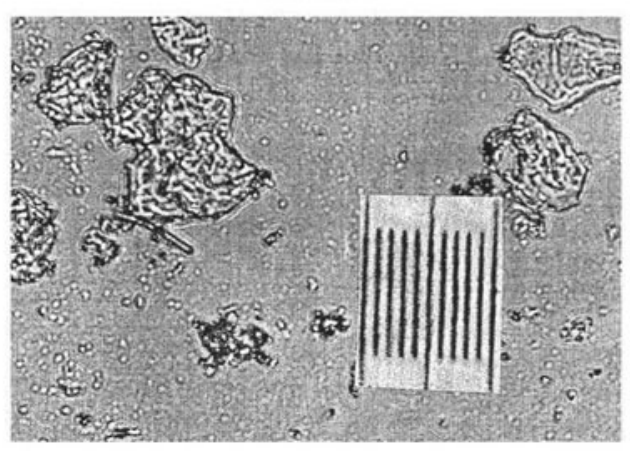

$716.57 \mathrm{~m}$

Fig. 2. Transmitted light photomicrographs of tephra particles, principally glass shards, in Siple Dome ice cores. Smallest scale subdivisions measure $5 \mu \mathrm{m}$.

Additional analysis of the dust-logger record by Bay and others (2006) suggests the existence of a much larger number of ash layers than was obtained by Bay and others (2001). Many of the additional spikes reported by Bay and others (2006) were from ice above $500 \mathrm{~m}$ and below $725 \mathrm{~m}$. Failure to visually record ash layers in cores deeper than 
Table 1. Average major element composition ( $\mathrm{wt} \%$ ) of tephra in the Siple Dome ice core. All analyses are normalized to $100 \mathrm{wt} \%$

$\begin{array}{llllllllllllllllllllll}\text { Sample Depth } & \text { Age } & N^{*} & \mathrm{P}_{2} \mathrm{O}_{5} & \mathrm{SiO}_{2} & \mathrm{SO}_{2} & \mathrm{TiO}_{2} & \mathrm{Al}_{2} \mathrm{O}_{3} & \mathrm{MgO} & \mathrm{CaO} & \mathrm{MnO} & \mathrm{FeO} & \mathrm{Na}_{2} \mathrm{O} & \mathrm{K}_{2} \mathrm{O} & F & \text { Tephra type } & \text { Source }\end{array}$ m $\quad$ kyr BP

\begin{tabular}{|c|c|c|c|c|c|c|c|c|c|c|c|c|c|c|c|c|c|}
\hline 9050 & 549.97 & 9.70 & 6 & 0.09 & 62.24 & 0.16 & 0.50 & 14.23 & 0.07 & 1.37 & 0.28 & 8.72 & 7.65 & 4.48 & 0.16 & Ash layer & Mount Berlin \\
\hline $\mathrm{SD}^{\dagger}$ & & & & 0.04 & 1.23 & 0.04 & 0.10 & 1.48 & 0.06 & 0.48 & 0.10 & 1.87 & 1.30 & 0.45 & 0.13 & & \\
\hline 9052 & 651.64 & 13.50 & 4 & 0.03 & 74.28 & 0.62 & 0.20 & 0.32 & 3.83 & 7.92 & 0.02 & 0.31 & 12.29 & 0.07 & 0.10 & Cloudy band & Non-volcanic \\
\hline SD & & & & 0.02 & 0.44 & 0.44 & 0.16 & 0.12 & 0.11 & 0.28 & 0.02 & 0.16 & 0.73 & 0.03 & 0.16 & & \\
\hline 9053 & 676.67 & 15.37 & 6 & 0.09 & 63.01 & 0.10 & 0.47 & 17.52 & 0.24 & 1.13 & 0.16 & 4.78 & 7.10 & 5.28 & 0.10 & Cloudy band & Undetermined \\
\hline SD & & & & 0.03 & 0.38 & 0.07 & 0.03 & 0.23 & 0.04 & 0.09 & 0.02 & 0.29 & 0.28 & 0.14 & 0.10 & & \\
\hline 9058 & 711.93 & 19.27 & 9 & 0.16 & 62.83 & 0.57 & 0.74 & 14.64 & 0.19 & 1.74 & 0.33 & 8.24 & 5.32 & 4.99 & 0.22 & Cloudy band & Mount Takahe? \\
\hline SD & & & & 0.11 & 1.45 & 0.46 & 0.19 & 0.58 & 0.11 & 0.41 & 0.07 & 1.21 & 0.89 & 0.36 & 0.16 & & \\
\hline 9061 & 733.32 & 24.11 & 12 & 0.06 & 62.01 & 0.19 & 0.58 & 13.63 & 0.02 & 1.29 & 0.36 & 9.84 & 6.88 & 4.94 & 0.19 & Ash layer & Undetermined \\
\hline SD & & & & 0.04 & 0.88 & 0.07 & 0.07 & 0.48 & 0.02 & 0.16 & 0.07 & 0.94 & 0.66 & 0.37 & 0.16 & & \\
\hline 9062 & 737.04 & 24.49 & 11 & 0.09 & 62.83 & 0.12 & 0.64 & 14.37 & 0.11 & 2.01 & 0.29 & 8.43 & 6.26 & 4.65 & 0.12 & Ash layer & Undetermined \\
\hline SD & & & & 0.04 & 0.54 & 0.06 & 0.08 & 0.26 & 0.06 & 0.23 & 0.03 & 0.40 & 0.40 & 0.10 & 0.13 & & \\
\hline 9063 & 759.24 & 28.52 & 10 & 0.06 & 63.55 & 0.11 & 0.51 & 13.69 & 0.01 & 1.14 & 0.26 & 8.48 & 7.37 & 4.54 & 0.27 & Ash layer & Mount Berlin \\
\hline SD & & & & 0.03 & 0.46 & 0.04 & 0.05 & 0.29 & 0.03 & 0.14 & 0.05 & 0.43 & 0.70 & 0.20 & 0.13 & & \\
\hline 9065 & 786.16 & 32.59 & 10 & 0.05 & 62.12 & 0.10 & 0.38 & 14.70 & 0.04 & 1.00 & 0.27 & 7.87 & 8.46 & 4.67 & 0.31 & Ash layer & Undetermined \\
\hline SD & & & & 0.04 & 0.97 & 0.03 & 0.04 & 0.37 & 0.04 & 0.09 & 0.04 & 0.60 & 0.54 & 0.08 & 0.17 & & \\
\hline $9051^{\mathrm{c}}$ & 596.92 & 11.16 & 9 & $\begin{array}{l}\text { Max } \\
0.10\end{array}$ & 58.64 & 0.04 & 1.05 & 14.20 & 2.88 & 7.02 & 0.31 & .33 & 2.82 & 0.56 & .04 & Ash layer & $\begin{array}{l}\text { Zoned eruption } \\
\text { Cerro Hudson }\end{array}$ \\
\hline & & & & $\begin{array}{l}\text { Min } \\
0.25\end{array}$ & 50.66 & 0.10 & 0.96 & 17.48 & 3.64 & 8.98 & 0.27 & 12.67 & 4.49 & 0.47 & 0.05 & & \\
\hline $9055^{*}$ & 708.23 & 18.31 & 12 & $\begin{array}{l}\text { Max } \\
0.02\end{array}$ & 62.43 & 0.06 & 0.14 & 22.24 & 0.36 & 3.48 & 0.01 & 1.16 & 8.70 & 1.19 & 0.21 & Ash layer & $\begin{array}{l}\text { Zoned or mul- } \\
\text { tiple eruptions; } \\
\text { undetermined }\end{array}$ \\
\hline & & & & $\begin{array}{l}\text { Min } \\
0.78\end{array}$ & 49.13 & 0.02 & 2.42 & 18.51 & 2.95 & 8.68 & 0.25 & 9.77 & 5.12 & 2.02 & 0.28 & & \\
\hline \multirow[t]{2}{*}{$9064^{*}$} & 778.16 & 31.60 & 7 & $\begin{array}{l}\operatorname{Max} \\
1.04\end{array}$ & 60.98 & 0.19 & 3.26 & 15.59 & 1.33 & 3.16 & 0.10 & 7.43 & 2.49 & 3.87 & 0.56 & Ash layer & \multirow[t]{2}{*}{$\begin{array}{l}\text { Mixed tephra; } \\
\text { undetermined }\end{array}$} \\
\hline & & & & $\begin{array}{l}\text { Min } \\
1.02\end{array}$ & 46.72 & 0.07 & 5.07 & 15.25 & 4.70 & 8.17 & 0.22 & 3.07 & 4.24 & 1.48 & 0.00 & & \\
\hline
\end{tabular}

${ }^{*} \mathrm{~N}$ is the number of samples analyzed. ${ }^{\dagger} \mathrm{SD}$ is the standard deviation.

*In ash layers exhibiting mixed tephra, zoned or multiple eruption characteristics the average compositions are based on analyses associated with the maximum/minimum $\mathrm{SiO}_{2}$ values.

$812 \mathrm{~m}$ can be attributed to the badly fractured condition of these cores, which in many sections were reduced to rubble. As the dust logger scans horizontally into the ice sheet from the walls of the drillhole it looks at a much larger volume of ice at any given depth than that represented by the $13.2 \mathrm{~cm}$ diameter core. The drillhole was kept filled with isobutyl acetate during coring, ensuring that the walls of the drillhole remained free of cracks. This also contributed to the larger number of suspected tephra layers recorded with the dust logger. As it is very unlikely that any particular infall of tephra would ever be uniformly deposited over the surface of the ice sheet, it is equally unlikely for a single core to contain a complete record of tephra deposition.

\section{PATTERN AND TIMING OF TEPHRA DEPOSITION}

An inspection of tephra records preserved in cores from both Siple Dome and Byrd has revealed a striking similarity in the distribution pattern of both the ash layers and cloudy bands. A dominant feature of both records is the peak in fallout of fine-grained dust in cloudy bands, which occurs at about the same relative depth, $66-70 \%$ of the ice-sheet thickness, at each location. This correspondence appeared even more striking when a provisional timescale for Siple Dome, based solely on our interpretation of annual-layer stratigraphy (Gow and Meese, 2002), correlated almost exactly (17 kyr BP) with the timing of peak fallout of cloudy bands at Byrd Station (Fig. 3). However, it should be noted that construction of this provisional timescale necessitated appreciable interpolation of the annual-layer count below $690 \mathrm{~m}$ because of gaps in the record resulting from severe fracturing of the core. Also, owing to the absence of identifiable annual-layer structure in the core at Byrd, the depth-age scale was calculated on the basis of a simplified ice-flow model (Nye, 1963 ) in conjunction with a constant rate of ice accumulation of $0.13 \mathrm{~m} \mathrm{a}^{-1}$ and a constant ice-sheet thickness of $2164 \mathrm{~m}$. Independent depth-age scales by Hammer and others (1994, 1997) and Blunier and others (1998) yielded dates of around $21 \mathrm{kyr} \mathrm{BP}$ for the peak of dust fallout at Byrd.

Although tephra distribution patterns in the Byrd and Siple Dome cores leave little doubt as to the contemporaneous nature of volcanic ash and dust deposition at both locations, it now appears that our use of a provisional stratigraphic timescale and our correlation with the Byrd tephra record has caused us to underestimate the peak fallout by $2-3 \mathrm{kyr}$, at least on the basis of age-dating results (Taylor and others, 2004b). Taylor and others (2004b) present a revised timescale for Siple Dome, extending from 8.2 to $30 \mathrm{kyr} B P$, synchronized with the GISP2 timescale (Meese and others, 1997) by correlating major features of the methane record from Siple Dome with those from GISP2 and GRIP (Brook and others, 1999). This revised timescale, 


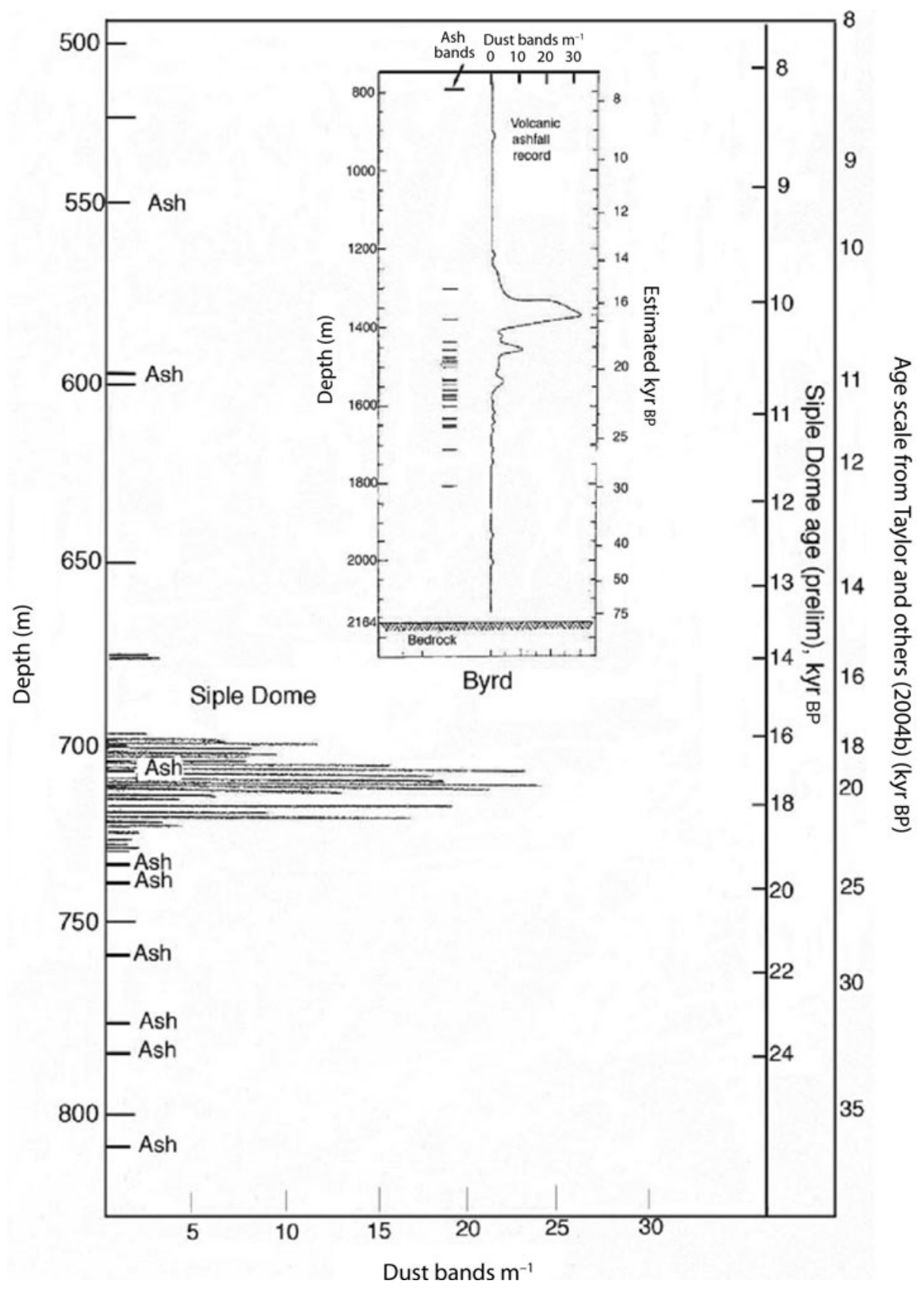

Fig. 3. Comparison of tephra records preserved in ice cores from Byrd Station (inset figure) and Siple Dome, showing strongly similar patterns of tephra deposition at two dispersed locations on the West Antarctic ice sheet. Age scale for Byrd is taken from Gow and Williamson (1971). The timescale for Siple Dome is provisional, based on interpretation of annual-layer stratigrapy (Gow and Meese, http:// nsidc.org/data/nsidc-0128.html). The extreme outer age scale (Taylor and others, 2004b) is the latest version of the Siple Dome dating based primarily on methane tie points between Siple Dome and GISP2 coupled to the highly resolved GISP2 depth-age scale.

indicated by the outer scale in Figure 3, yields a date of about $19.4 \mathrm{kyr}$ BP at a depth of $711 \mathrm{~m}$ for the volcanic dust peak at Siple Dome. Assuming contemporaneous tephra deposition at Byrd and Siple Dome, this places the timing of peak dust fallout more or less midway between $21 \mathrm{kyr} B \mathrm{P}$, from the Byrd core timescales of Hammer and others (1997) and Blunier and others (1998), and $17 \mathrm{kyrBP}$, from the provisional stratigraphic timescale for Siple Dome (Gow and Meese, http://nsidc.org/data/nsidc-0128.html) and the model-generated date for the Byrd core (Gow and Williamson, 1976). A high-resolution timescale for the Siple Dome core has not been resolved. For the purpose of this paper we have applied the Taylor and others (2004b) timescale and its extension to $57 \mathrm{kyr}$ BP by Brook and others (2005) to the tephra fallout record at Siple Dome (Fig. 3), despite the fact that age uncertainties for this timescale are as large as $\pm 2 \mathrm{kyr}$ at $722 \mathrm{~m}$ (Taylor and others, 2004b) where an abrupt 30\%o change in the $\delta \mathrm{D}_{\text {ice }}$ occurs relatively close to the volcanic dust peak at around $711 \mathrm{~m}$.

Final resolution of a robust timescale for Siple Dome is important to determine the precise timing of widespread deposition of tephra at Siple Dome and Byrd Station. Discrete tephra layers, chemically characterized and dated, will provide diagnostic markers for cross-correlation of tephra deposits in cores from West Antarctica, such as the inland West Antarctic ice sheet core. In East Antarctica there is also significant evidence of widespread deposition of tephra preserved in ice cores, from Dome Fuji (Fujii and 
others, 1999; Kohno and others, 2004), Vostok (Legrand and others, 1988; Basile and others, 2001) and Dome C (Castellano and others, 2005; Narcisi and others, 2005). A total of 26 discrete tephra layers were identified in the Dome Fuji core (Kohno and others, 2004), several of which could be correlated with Vostok tephra. According to Fujii and others (1999), large numbers of cloudy bands concentrated in a zone between 480 and $715 \mathrm{~m}$ at Dome Fuji probably correspond with the cloudy band zone in the Byrd core. Much of the tephra preserved in cores from East Antarctica appears to have originated from sources within and around Antarctica, including volcanoes in the South Shetland Islands, the South Sandwich Islands, the Andes, Marie Byrd Land, West Antarctica, and Victoria Land, East Antarctica.

\section{A CASE FOR ENHANCED THINNING OF TEPHRA-RICH ICE}

The case for contemporaneous deposition of tephra at Siple Dome and Byrd Station is predicated on the observation that very similar patterns of tephra fallout are preserved in ice cores from both locations. Such a correlation invites comment as to the time interval over which the tephra was deposited. This situation applies especially to the finegrained tephra component, volcanic dust, the bulk of which ( $>90 \%$ at both locations) is estimated to have taken 7000 8000 years to deposit, based on the latest revised timescale for Siple Dome (Taylor and others, 2004b; Brook and others, 2005) indicated in Figure 3. However, the ice thickness over which this deposition of volcanic dust occurred varies dramatically between the two locations: $33 \mathrm{~m}$ (697-730 m) at Siple Dome and 240m (1300-1540m) at Byrd Station. This nearly $7.3: 1$ disparity in the ice thickness for contemporaneously deposited volcanic dust at Byrd Station and Siple Dome reduces to about 3.0:1 if the bulk tephra deposition (ash and dust combined) occurred between 1300 and $1650 \mathrm{~m}$ at Byrd and between 697 and $812 \mathrm{~m}$ at Siple Dome. Either way, these disparities indicate (i) low or no accumulation rates for an extended period of time at Siple Dome and/or (ii) a much enhanced degree of ice-sheet thinning at Siple Dome compared to that at Byrd Station. The precise nature of the deformation needed to achieve this is not known unless dynamic interaction between the dome ice and Kamb and Bindschadler Ice Streams that flank it is in some way accelerating thinning of tephra-rich ice at Siple Dome.

\section{SOURCES OF TEPHRA IN THE SIPLE DOME AND BYRD ICE CORES}

The bulk of tephra observed visually in the Siple Dome ice core occurred between 550 and $812 \mathrm{~m}$. Dunbar and others (2003) and Kurbatov and others (2006) analyzed tephra particles associated with elevated sulfate signatures in Siple Dome ice cores. Results of electron microprobe analyses by Dunbar and others (2003) on glass shards from seven locations in the top $100 \mathrm{~m}$ of two Siple Dome ice cores yielded major elemental compositions that indicated derivation from volcanic sources in East Antarctica, including Mount Melbourne, the Pleiades Volcano and small eruptive centers in the Royal Society Range. Kurbatov and others (2006), also relying primarily on elevated sulfate to guide their sampling of tephra particles in Holocene ice at Siple Dome, conducted microprobe fingerprinting of the particles to compile a 12000 year record of explosive volcanism in Antarctica. A number of the particles could be matched with eruptive sources in both East and West Antarctica, including the Balenny Islands, the Pleiades Volcano, Mount Takahe and Mount Berlin. However, the tephra particles in many of the layers analyzed by Kurbatov and others (2006) could not be positively identified with volcanic sources either within or from outside Antarctica. A map from Kurbatov and others (2006) shows the location of relevant volcanoes (Fig. 4).

Cenozoic alkali volcanics are widespread throughout much of Marie Byrd Land (LeMasurier and Wade, 1976; Kyle and Jezek, 1978; Kyle and others, 1981) and, as originally suggested by Gow and Williamson (1971), are the most likely source of tephra in the Byrd core. Initial microprobe studies by Kyle and Jezek (1978) on volcanic glass shards from three tephra layers at Byrd showed that all three were of peralkaline trachyte composition. Compositionally, they appeared very similar chemically to a peralkaline trachyte sample from Mount Takahe, which Kyle and Jezek (1978) considered to be the most likely source of the three tephra layers in the Byrd core. Additional measurements by Kyle and others (1981) served to reinforce their view that the Byrd core tephra layers originated from Mount Takahe. Palais (1985a, b) and Palais and others (1988) similarly identified Mount Takahe as the likely source of a number of additional tephra layers in the Byrd core. However, Palais (1985b) acknowledged that Mount Berlin could not be ruled out as an alternative source. Wilch and others (1999) also recognized Mount Takahe and Mount Berlin as potential sources for Byrd core tephra but favored Mount Berlin as the primary source, based largely on age and geochemical characteristics. Wilch and others (1999) provide convincing evidence that a composite sample of five Byrd core ash layers, deposited 20-30 kyr BP (encompassing deposition of the bulk of the coarser-grained ash layers at Byrd), is geochemically very similar to Mount Berlin volcanics dated at $20-27 \mathrm{kyr} B \mathrm{PP}$ by ${ }^{40} \mathrm{Ar} /{ }^{39} \mathrm{Ar}$. Only the youngest ash layer, estimated at $7.5 \mathrm{kyr} B \mathrm{P}$, located at a depth of $788 \mathrm{~m}$ in the Byrd core could be correlated geochemically by Wilch and others (1999) to the youngest dated rock (8.2 $\pm 5.4 \mathrm{kyr} B \mathrm{BP})$ erupted from Mount Takahe.

Given the close proximity of Byrd Station to Mount Takahe, a case could be made for considering Mount Takahe as more than a secondary source of tephra in the Byrd core. This tephra was originally deposited upstream from its present location at Byrd at an estimated distance of $\sim 350-400 \mathrm{~km}$ from Mount Takahe. This estimate takes into account the direction and magnitude of ice flow during the last 15000-30000 years (Whillans, 1979). Mount Berlin would be located no closer than about $620 \mathrm{~km}$, from where the tephra would have been originally deposited on the surface of the ice sheet upstream from Byrd Station. Considering such factors as mean particle size $(30-50 \mu \mathrm{m}$ for ash layers), geochemical characteristics of the ash and likely prevailing wind direction, Mount Takahe must be considered somewhat more than a secondary source of tephra in the Byrd core. Only glass shards from a composite sample of coarser-grained ash layers in the Byrd core have been subject to geochemical analysis by Wilch and others (1999). Glass shards from the much more abundant cloudy bands do not appear to have been analyzed. However, Mount Berlin is located much closer to Siple Dome $(670 \mathrm{~km})$ than Mount Takahe $(940 \mathrm{~km})$, and must be 


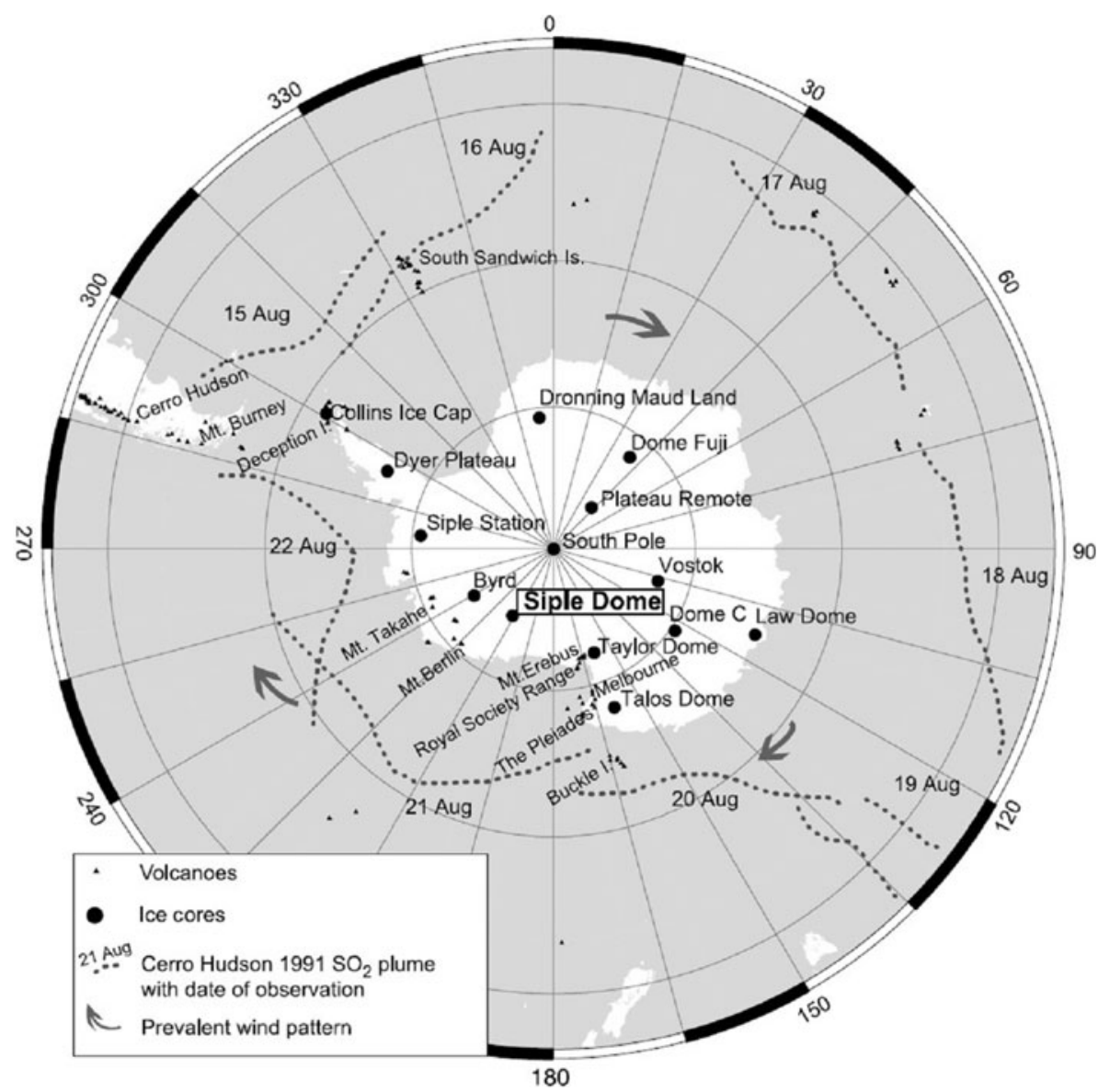

Fig. 4. Locations of volcanoes and ice-core sites in and around Antarctica, from Kurbatov and others (2006).

considered a more likely source of tephra in the Siple Dome core. Alternatively, eruptions may have been occurring simultaneously at both volcanoes and possibly others in Marie Byrd Land.

\section{CLIMATIC IMPLICATIONS OF TEPHRA ERUPTIONS}

Widespread occurrence of volcanic ash in ice cores at Byrd testifies to a period of sustained volcanic activity, estimated to have taken place between 30 and $16 \mathrm{kyr}$ BP. Gow and Williamson (1971) speculated, on the basis of stable-isotope data, that a significant cooling of the atmosphere over Antarctica occurred at the same time (Fig. 5). This cooling trend did not terminate until deposition of ash had virtually ceased, suggesting a cause-and-effect relationship involving the solar-depleting effect of volcanic dust in the Antarctic atmosphere.

Although there is some skepticism about the link between climate change and volcanic activity, there is a great deal of evidence indicating that volcanic eruptions are capable of triggering or enhancing long-term cold events (e.g. Bray, 1974; Gow and Williamson, 1976; Hammer and others, 1980; Kyle and others, 1981; Bryson, 1989; Ramino and Self, 1993; Cole-Dai and others, 1997; Adams and others, 2003; Castellano and others, 2005). Bay and others (2004) reported a $>99 \%$ correlation between volcanic horizons measured in the Siple Dome core and the onset of millennial cold periods in Greenland during the last glacial period. Bay and others (2006) extended this to the analysis of volcanic sulfate peaks in ice cores from Vostok, EPICA Dome C and
GISP2. Analytical results show a strong connection between globally coincident volcanism and abrupt cooling during the last glacial period.

The tephra fallout record vs the $\delta D_{\text {ice }}$ profile, plotted as a function of age at Siple Dome, is presented in Figure 6. The section designated $A$ includes the bulk $(>90 \%)$ of volcanic dust deposited between 22 and 17.5 kyr BP. Section $(A+B)$ encompasses the period between 35 and $17.5 \mathrm{kyr} B P$, during which protracted deposition of the bulk of the tephra (ash and dust combined) occurred. Possible climate changes relating to the eruption and delayed fallout of tephra preserved in the Siple Dome ice core include the observation of a significant decline in $\delta \mathrm{D}_{\text {icee }}$ symptomatic of cooling surface air temperatures, between 22 and $17.5 \mathrm{kyr}$ BP that coincided with peak influx of fine-grained volcanic dust, preserved as cloudy bands in the core. Except for a precipitous, 30\% increase in $\delta D_{\text {ice }}$ at $\sim 722 \mathrm{~m}$ depth, immediately prior to the cooling event beginning at $22 \mathrm{kyr} B \mathrm{P}, \delta \mathrm{D}_{\text {ice }}$ values underwent a persistent decrease between 36 and $22 \mathrm{kyr}$ BP. This apparent decline in surface temperatures at Siple Dome occurred coincidentally with the onset of fallout of the coarser-grained volcanic ash. It is possible that some of the tephra layers recorded with the dust logger are responsible for some of the excursions in $\delta \mathrm{D}_{\text {ice }}$ in deeper ice at Siple Dome (Bay and others, 2006).

The abrupt change in $\delta \mathrm{D}_{\text {ice }}$ at $722 \mathrm{~m}$ (Fig. 6) raises questions about its origin and its rapid nature. Taylor and others (2004b) have interpreted this change (with caveats) as a warming event in which temperatures increased by $5-6^{\circ} \mathrm{C}$ in just a few decades. However, results of high-resolution 


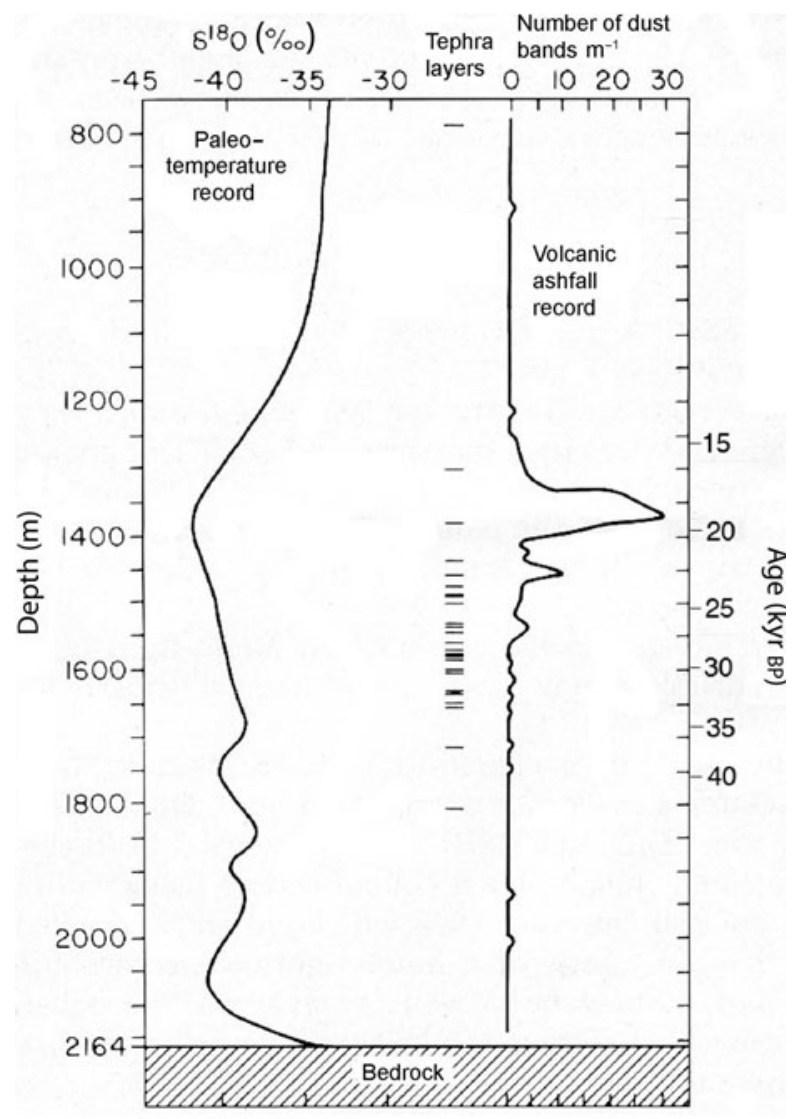

Fig. 5. Correlation of tephra infall record in the Byrd ice core with the generalized isotopic paleotemperature curve based on stableisotope data from Epstein and others (1970). Figure adapted from Gow and Williamson (1971). Timescale is the same as that for Siple Dome assuming that tephra deposition was essentially contemporaneous at both locations. See text for additional details.

sampling have confirmed the abrupt change in $\delta D_{\text {ice }}$ occurred in less than $5 \mathrm{~cm}$. If the warming at $722 \mathrm{~m}$ was enough to cause appreciable melting of previously deposited snow, this could result in compressing a firn record several meters thick into a few centimeters. Severinghaus and others (2003) observed a step-like decrease in the $\delta^{40} \mathrm{Ar}$ composition of air trapped in ice at $727 \mathrm{~m}, 5 \mathrm{~m}$ deeper than the abrupt increase in water isotopes. Severinghaus and others (2003) attributed the decrease in gas isotopes at $727 \mathrm{~m}$ to an $18 \mathrm{~m}$ reduction in the firn diffusive column height. They suggest that the offset between the $727 \mathrm{~m}$ event and the depth at which the abrupt change in $\delta \mathrm{D}_{\text {ice }}$ occurs rules out tectonic dislocation or a hiatus in snow accumulation.

Taylor and others (2004a) have suggested (i) that an abrupt change in the gas and ice isotopes would also occur if part of the ice dome overran older ice or if subsurface flow conveyed ice of different ages into contact with each other and (ii) that ice dynamics, such as an abrupt change in surface elevation of ice streams flanking Siple Dome, could also have created the step increase in $\delta D_{\text {ice. }}$. The possibility exists that ice dynamics could be playing a major role in determining the origin of the abrupt change in $\delta D_{\text {ice }}$ at $722 \mathrm{~m}$. This possibility should not be ignored, especially in light of the rheological characteristics and $c$-axis fabrics of particle-rich ice from 700-730 m discussed below.

\section{POSSIBLE RHEOLOGICAL IMPLICATIONS OF TEPHRA DEPOSITION}

As indicated in Figure 7, an abrupt change in $c$-axis fabric, beginning at $\sim 700 \mathrm{~m}$ and continuing to $800 \mathrm{~m}$, occurred coincidentally with sustained deposition of tephra. This fabric, characterized by a tight clustering of $c$ axes about the vertical, was accompanied by a substantial, ten-fold, decrease in crystal size (Gow and Meese, http://nsidc.org/ data/nsidc-0128.html; DiPrinzio and others, 2005). The crystals also exhibited a fragmented appearance and were further characterized by widespread undulatory extinction. Such a change in crystal structure is immediately preceded in ice from above $700 \mathrm{~m}$ by a fabric in which the $c$ axes had become preferentially oriented in a vertical plane. This socalled girdle fabric first appeared at $\sim 320 \mathrm{~m}$ depth and was accompanied by a significant increase in the size of

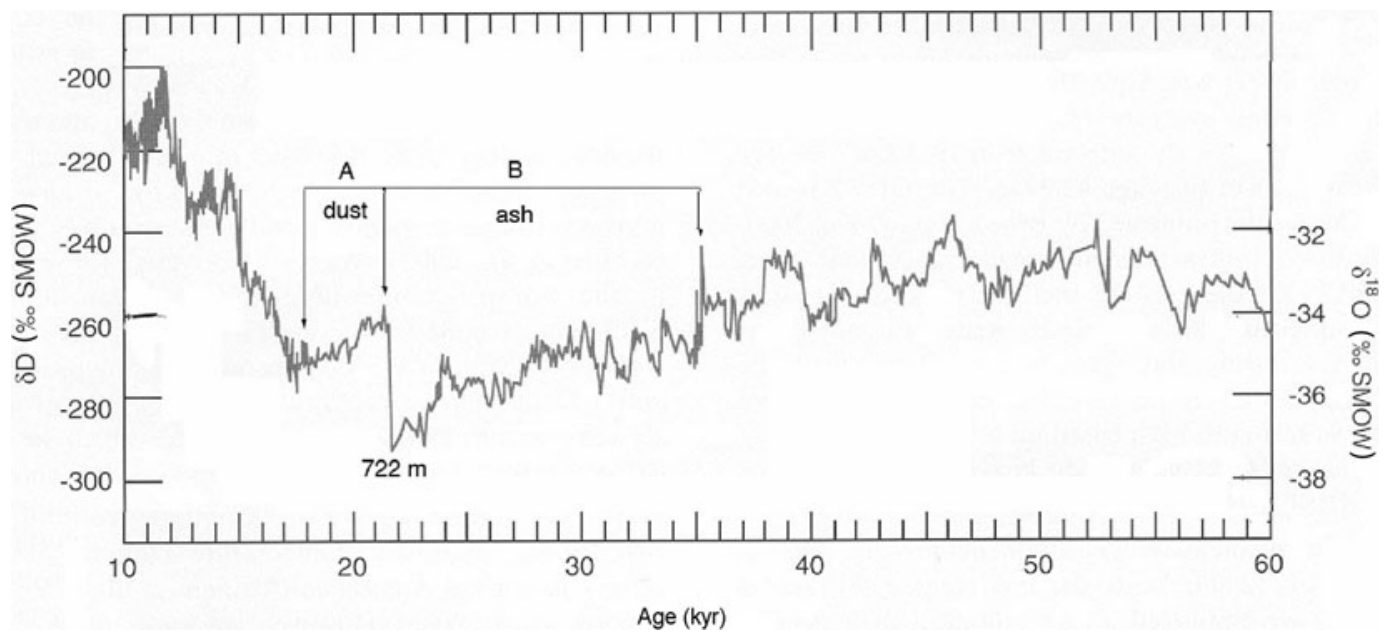

Fig. 6. Tephra fallout record vs the $\delta D_{\text {ice }}$ profile plotted as a function of age at Siple Dome. Isotope profile adapted from Brook and others (2005). The section designated A includes the bulk ( $>90 \%)$ of volcanic dust deposited between 22 and $17.5 \mathrm{kyr}$ BP. Section (A + B) encompasses the period during which the bulk of tephra (ash and dust) was originally deposited, between 17.5 and $35 \mathrm{kyr}$ BP. Salient features of the plot vs the $\delta D_{\text {ice }}$ profile with possible climate-change implications are described more fully in the text. SMOW: Standard Mean Ocean Water. 

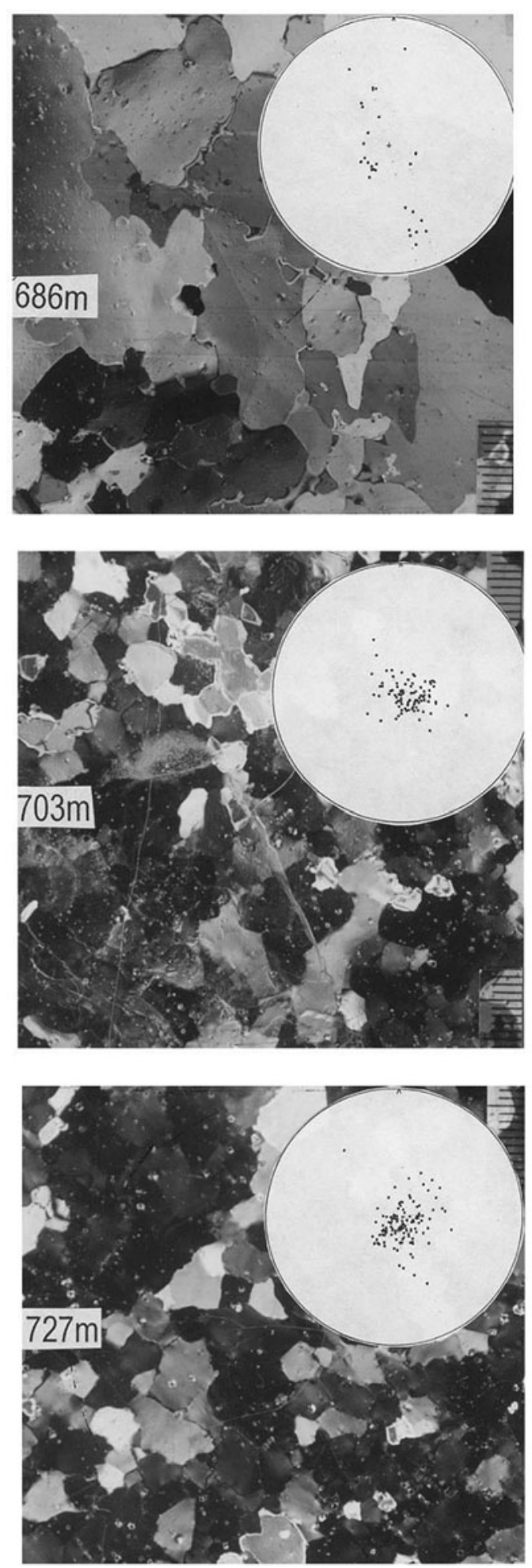
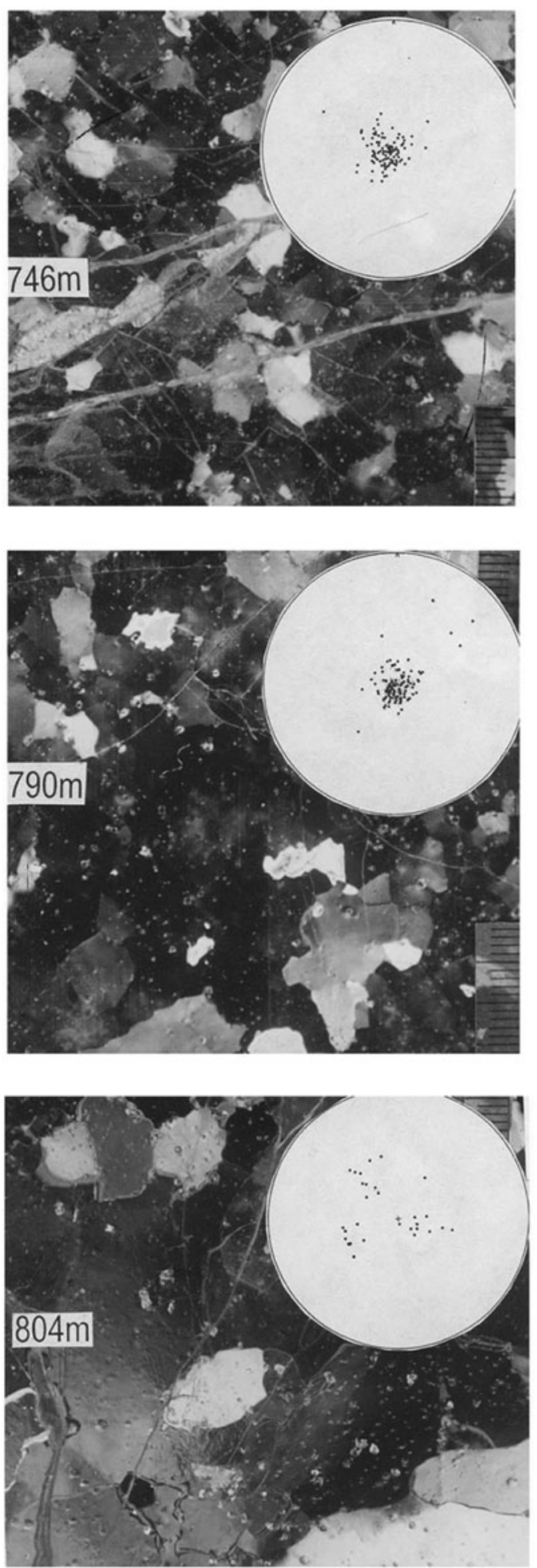

Fig. 7. Textures and $c$-axis fabrics of selected thin sections of Siple Dome ice, demonstrating the abrupt nature of changes observed in the crystalline structure between 686 and $804 \mathrm{~m}$. Smallest scale subdivisions in each thin section, photographed between crossed polarizers, measure $1 \mathrm{~mm}$.

the crystals. Around $800 \mathrm{~m}$, the ice underwent further transformation to very coarse-grained ice with $c$ axes now redistributed into several maxima about the vertical. In short, this fine-grained, strongly sheared layer at 700-800 m is sandwiched between coarse-grained ice above and below it. For detailed discussions of crystalline texture and $c$-axis fabric profiles see DiPrinzio and others (2005) and Gow and Meese (2007).
In ice sheets, the formation of girdle-type fabrics is generally attributed to ice deforming in uniaxial longitudinal extension (Fujita and others, 1987; Alley, 1988; Lipenkov and others, 1989; Gow and Engelhardt, 2000), whereas the formation of a tight clustering of $c$ axes is associated with deformation dominated by simple shear in a plane normal to the $c$ axes (Rigsby, 1955; Gow and Williamson, 1976; Alley, 1988; Gow and others, 1997; 
DiPrinzio and others, 2005). The girdle fabric, near the transition to the strong $c$-axis vertical fabric, is also characterized by some clustering of $c$ axes in the vertical. According to the theoretical modeling results of Thorsteinsson (2002) such a fabric is a result of pure shear. The resultant dramatic transition or flip-flop between two highly contrasted fabric patterns at $\sim 700 \mathrm{~m}$ not only reflects an abrupt change in the nature of the stress-strain field, it also signals a major change in the rheological properties of the ice. Such an abrupt change in texture or fabric has not been observed in cores from Dome $F$ (Azuma and others, 1999) or Dome C (Wang and others, 2003) in East Antarctica where ice is three times thicker than at Siple Dome. Such an abrupt change in rheological properties related to the formation of a single pole fabric from approximately 700 to $800 \mathrm{~m}$ is probably related to the widespread incorporation of tephra. A strong clustering of $C$ axes about the vertical was also observed at Byrd, where it was attributed to simple shear and also occurs coincidentally with the onset and termination of tephra fallout, between 1300 and $1800 \mathrm{~m}$.

Reports based on field observations show that, in some instances, the plastic deformation of ice is apparently enhanced by the incorporation of debris. According to Butkovich and Landauer (1959) and Swinzow (1962), for example, slightly dirty ice in the Tuto tunnel near the edge of the Greenland ice sheet was observed to deform more readily than clean ice. Swinzow (1962) also reported that silt bands in the Tuto tunnels coincided with surfaces of concentrated differential movement. However, laboratory testing with debris-bearing ice has produced somewhat conflicting results. Jacka and others (2003) presented a detailed summary of the flow characteristics of debrisbearing ice; these include results based largely on mechanical testing of sand-bearing ice and others based on field examination of the structural properties of glacial ice; including basal ice in which the impurity levels were relatively low. Jacka and others (2003) performed experiments on sand-laden ice in either vertical compression or simple shear and found no significant dependence on flow rate for sand content up to $15 \%$ by volume. However, the experimental results of Song and others (2005) show that particles averaging $50 \mu \mathrm{m}$ in diameter significantly increase the creep rate of granular ice for particle concentrations of up to $4 \mathrm{wt} \%$. The minimum strain rates of ice with particle concentrations between 0.5 and $4 \mathrm{wt} \%$ were found to increase by $100 \%$ compared to particle-free ice.

However, Swinzow's (1962) observations, in particular, seem to indicate that both the particle size and concentration of particles in the ice may be significant factors in determining the degree to which the plastic deformation of ice is increased or decreased. At both Byrd and Siple Dome, tephra particles in the ash layers averaged $\sim 50 \mu \mathrm{m}$, which would be equivalent to coarse-grained silt; dust in the cloudy bands averaged $\sim 5 \mu \mathrm{m}$, at the lower end of the silt size range. Particle concentrations were not measured in tephra layers at Siple Dome. However, a cloudy band at Byrd with a particle concentration of just $4 \times 10^{-5} \mathrm{~g} \mathrm{~cm}^{-3}$ was estimated to contain $15 \times 10^{6}$ particles $\mathrm{cm}^{-3}$ in the size range $0.5-10 \mu \mathrm{m}$ (Gow and Williamson, 1971). Similarly to tephra layers at Byrd, those at Siple Dome possess an ultrafine oriented crystal texture which, together with the undulose extinction characteristics of the crystals and their fragmented appearance, certainly suggests that such layers of very fine-grained ice may be actively involved in localized shearing in the deeper parts of Siple Dome ice.

Pettit (2003) used Siple Dome borehole sonic velocities to describe a layer between 700 and $800 \mathrm{~m}$ where the crystals are vertically aligned so tightly it could be considered a single crystal. The horizontal velocity fields have a kink at this depth, indicating that the layer acts as a false bed, with shear concentrated in it. Pettit's (2003) models show that because of this false-bed effect, most of the deformation is within and above this layer of ice.

\section{CONCLUSIONS}

Sporadic deposition of volcanic ash and dust was first observed at around $500 \mathrm{~m}$ in the Siple Dome core. It continued to $650 \mathrm{~m}$, before the onset of a major period of ash and dust fallout beginning at $\sim 675 \mathrm{~m}$ and increasing substantially at $\sim 700 \mathrm{~m}$. Peak fallout of volcanic dust occurred at 707-713 m, with additional pulses down to $730 \mathrm{~m}$, followed by spasmodic deposition of ash to just below $800 \mathrm{~m}$. A total of 10 ash layers and more than 300 cloudy bands were identified. Results obtained with a down-hole optical dust logger have confirmed the existence of these and additional ash layers both above $700 \mathrm{~m}$ and below $800 \mathrm{~m}$. Particle sizes averaged $\sim 50 \mu \mathrm{m}$ in ash layers and $\sim 5 \mu \mathrm{m}$ in cloudy bands. Particles consisted primarily of glass shards, with lesser amounts of crystalline material and groundmass fragments. Two ash layers have been identified with eruptions from Mount Berlin, based on glass-shard chemistry. Two other ash layers have been tentatively linked with Mount Takahe and Cerro Hudson. The origins of several other chemically analyzed tephra layers remain to be determined.

The distribution pattern of ash and dust at Siple Dome closely paralleled that observed in the Byrd core based on annual-layer stratigraphy (Gow and Meese, 2002), indicating contemporaneous deposition of tephra at the two locations. However, attempts to cross-correlate individual tephra layers at Siple Dome and Byrd have proven elusive. Several independent timescales have been calculated for both Siple Dome and Byrd; the one adopted here for Siple Dome is that of Taylor and others (2004b) and its extension to $57 \mathrm{kyr} \mathrm{BP}$ by Brook and others (2005). This timescale was synchronized with the GISP2 timescale by correlating major features of the Siple Dome methane record with corresponding features in the GISP2 and GRIP methane records. This timescale dates the peak dust fallout at Siple Dome at $\sim 19.4 \mathrm{kyr}$ BP, almost midway between the $21 \mathrm{kyr}$ BP calculated by Blunier and others (1998) for the dust peak at Byrd and the 17 kyr BP estimated by Gow and Williamson (1971).

The bulk of fine-grained tephra, concentrated between 697 and $730 \mathrm{~m}$, appears to have undergone drastic thinning compared to that at Byrd for contemporaneously deposited tephra. The precise nature of the thinning, based on dramatic differences in the age-ice thickness relationships of tephra-rich ice at these two locations, is not known, but one possibility is that dynamic interaction between Siple Dome and Kamb and Bindschadler Ice Streams, which flank it, is in some way accelerating the thinning of tephra-rich ice at Siple Dome.

Possible climatic implications related to the eruption of tephra include the observation of a small but significant cooling event coincident with peak influx of volcanic dust between 22 and $17.5 \mathrm{kyr}$ BP. This cooling trend appears to 
continue to $\sim 35 \mathrm{kyr} B \mathrm{P}$, where the onset of concentrated ash deposition begins. A rapid increase in $\delta D_{\text {ice }}$ at $722 \mathrm{~m}$, indicative of a $5-6^{\circ} \mathrm{C}$ warming, is probably not the result of an actual climate event. Such an event has not been observed elsewhere, and a localized climate event of this magnitude is unlikely. An alternative explanation for the warming event of $5-6^{\circ} \mathrm{C}$ in $\delta D_{\text {ice }}$ is that it reflects a discontinuity within the ice at $722 \mathrm{~m}$. The dynamics of such a discontinuity could conceivably involve underflow of ice from higher elevations upstream of the Siple Dome drill site.

Concurrent with the sustained infall of volcanic ash and dust between 700 and $800 \mathrm{~m}$, an abrupt change to a strong shear fabric in which crystallographic $c$ axes become tightly clustered about the vertical was observed. This change in fabric from a vertical girdle in ice above $700 \mathrm{~m}$ to a multimaxima fabric below $800 \mathrm{~m}$ was accompanied by a dramatic decrease in crystal size in the $700-800 \mathrm{~m}$ zone relative to ice above and below it. Based on rheology, flow models and vertical strain-rate measurements (Pettit, 2003) it appears that localized shear displacement is occurring along discrete planes associated with very fine-grained layers of dust containing large numbers of silt-sized tephra particles within and above this zone of ice between 700 and $800 \mathrm{~m}$, from the last ice age.

\section{ACKNOWLEDGEMENTS}

This work was supported by the Office of Polar Programs, US National Science Foundation under grant OPP-0126212. Additional support was provided by the US Army Engineer Research and Development Center, Cold Regions Research and Engineering Laboratory (ERDC-CRREL). We thank B. Elder of ERDC-CRREL and the curatorial staff of the NICL for assistance in processing the Siple Dome ice core. We thank A. Kurbatov and N. Dunbar for processing and electron microprobe analyses of tephra particles. We also thank R.LeB. Hooke for insightful comments.

\section{REFERENCES}

Adams, J.B., M.E. Mann and C.M. Ammann. 2003. Proxy evidence for an El Niño-like response to volcanic forcing. Nature, 426(6964), 274-278.

Alley, R.B. 1988. Fabrics in polar ice sheets: development and prediction. Science, 240(4851), 493-495.

Azuma, N. and 6 others. 1999. Textures and fabrics in the Dome F (Antarctica) ice core. Ann. Glaciol., 29, 163-168.

Basile, I., J.R. Petit, S. Touron, F.E. Grousset and N.I. Barkov. 2001. Volcanic tephra in Antarctic (Vostok) ice-cores: source identification and atmospheric implications. J. Geophys. Res., 106(D23), 31, 915-31,931.

Bay, R.C., B.P. Price, G.D. Clow and A.J. Gow. 2001. Climate logging with a new rapid optical technique at Siple Dome. Geophys. Res. Lett., 28(24), 4635-4638.

Bay, R.C., N. Bramall and B.P. Price. 2004. Bipolar correlation of volcanism with millennial climate change. Proc. Nat. Acad. Sci. USA (PNAS), 101(17), 6341-6345.

Bay, R.C. and 6 others. 2006. Globally synchronous ice core volcanic tracers and abrupt cooling during the last glacial period. J. Geophys. Res., 111(D11), D11108. (10.1029/2005JD006306.)

Blunier, T. and E.J. Brook. 2001. Timing of millennial-scale climate change in Antarctica and Greenland during the last glacial period. Science, 291(5501), 109-112.

Blunier, T. and 10 others. 1998. Asynchrony of Antarctic and Greenland climate change during the last glacial period. Nature, 394(6695), 739-743.
Bray, J.R. 1974. Volcanism and glaciation during the past 40 millennia. Nature, 252(5485), 679-680.

Brook, E.J., S. Harder, J. Severinghaus and M. Bender. 1999. Atmospheric methane and millennial-scale climate change. In Clark, P.U., R.S. Webb and L.D. Keigwin, eds. Mechanisms of global climate change at millennial time scales. Washington, DC, American Geophysical Union, 165-176.

Brook, E. and 6 others. 2005. Timing of millennial-scale climate change at Siple Dome, West Antarctica, during the last glacial period. Quat. Sci. Rev., 24(12-13), 1333-1343.

Bryson, R.A. 1989. Late Quaternary volcanic modulation of Milankovitch climate forcing. Theor. Appl. Climatol., 39(3), 115-125.

Butkovich, T.R. and J.K. Landauer. 1959. A grid technique for measuring ice tunnel deformation. J. Glaciol., 3(26), 508-511.

Castellano, E. and 9 others. 2005. Holocene volcanic history as recorded in the sulfate stratigraphy of the European Project for Ice Coring in Antarctica Dome C (EDC96) ice core. J. Geophys. Res., 110(D6), D06114. (10.1029/2004JD005259.)

Cole-Dai, J., E. Mosley-Thompson and L.G. Thompson. 1997. Annually resolved Southern Hemisphere volcanic history from two Antarctic ice cores. J. Geophys. Res., 102(D14), 16,761-16,771.

DiPrinzio, C.L., L.A. Wilen, R.B. Alley, J.J. Fitzpatrick, M.K. Spencer and A.J. Gow. 2005. Fabric and texture at Siple Dome, Antarctica. J. Glaciol., 51(173), 281-290.

Dunbar, N.W., G.A. Zielinski and D.T. Voisin. 2003. Tephra layers in the Siple and Taylor Dome ice cores, Antarctica: sources and correlations. J. Geophys. Res., 108(B8), 2374. (10.1029/ 2002JB002056.)

Epstein, S., R.D. Sharp and A.J. Gow. 1970. Antarctic Ice Sheet: stable isotope analyses of Byrd Station cores and interhemispheric climatic implications. Science, 168(3939), 1570-1572.

Fujii, Y. and 8 others. 1999. Tephra layers in the Dome Fuji (Antarctica) deep ice core. Ann. Glaciol., 29, 126-130.

Fujita, S., M. Nakawo and S. Mae. 1987. Orientation of the 700-m Mizuho core and its strain history. Proc. NIPR Symp. Polar Meteorol. Glaciol., 122-131.

Gow, A.J. and H. Engelhardt. 2000. Preliminary analysis of ice cores from Siple Dome, West Antarctica. In Hondoh, T., ed. Physics of ice core records. Sapporo, Hokkaido University Press, 63-82.

Gow, A.J. and D.A. Meese. 2002. On the distribution and timing of volcanic ash and dust fallout in the Siple Dome ice core. Eos, 83(19), A32B-05.

Gow, A.J. and D.A. Meese. 2007. Physical properties, crystalline textures and $c$-axis fabrics of the Siple Dome (Antarctica) ice core. J. Glaciol., 53(183), 573-584.

Gow, A.J. and T. Williamson. 1971. Volcanic ash in the Antarctic ice sheet and its possible climatic implications. Earth Planet. Sci. Lett., 13(1), 210-218.

Gow, A.J. and T. Williamson. 1976. Rheological implications of the internal structure and crystal fabrics of the West Antarctic ice sheet as revealed by deep core drilling at Byrd Station. Geol. Soc. Am. Bull., 87(12), 1665-1677.

Gow, A.J. and 6 others. 1997. Physical and structural properties of the Greenland Ice Sheet Project 2 ice cores: a review. J. Geophys. Res., 102(C12), 26,559-26,575.

Hammer, C.U., H.B. Clausen and W. Dansgaard. 1980. Greenland ice sheet evidence of post-glacial volcanism and its climatic impact. Nature, 288(5788), 230-235.

Hammer, C.U., H.B. Clausen and C.C. Langway, Jr. 1994. Electrical conductivity method (ECM) stratigraphic dating of the Byrd Station ice core, Antarctica. Ann. Glaciol., 20, 115-120.

Hammer, C.U., H.B. Clausen and C.C. Langway, Jr. 1997. 50,000 years of recorded global volcanism. Climatic Change, 35(1),1-15.

Jacka, T.H., S. Donoghue, J. Li, W.F. Budd and R.M. Andersen. 2003. Laboratory studies of the flow rates of debris-laden ice. Ann. Glaciol., 37, 108-112.

Kohno, M., Y. Fujii and T. Hirata. 2004. Chemical composition of volcanic glasses in visible tephra layers found in a $2503 \mathrm{~m}$ deep ice core from Dome Fuji, Antarctica. Ann. Glaciol., 39, 576-584. 
Kurbatov, A.V. and 6 others. 2006. A 12,000 year record of explosive volcanism in the Siple Dome Ice Core, West Antarctica. J. Geophys. Res., 111(D12), D12307. (10.1029/ 2005JD006072.)

Kyle, P.R. and P.A. Jezek. 1978. Compositions of three tephra layers from the Byrd Station ice core, Antarctica. J. Volcan. Geotherm. Res., 4(4), 225-232.

Kyle, P.R., P.A. Jezek, E. Mosley-Thompson and L.G. Thompson. 1981. Tephra layers in the Byrd Station ice core, Antarctica, and their climatic importance. J. Volcan. Geotherm. Res., 11, 29-39.

Legrand, M.R., C. Lorius, N.I. Barkov and V.N. Petrov. 1988. Vostok (Antarctica) ice core: atmospheric chemistry changes over the last climatic cycle (160,000 years). Atmos. Environ., 22(2), 317-331.

LeMasurier, W.E. and F.A. Wade. 1976. Volcanic history in Marie Byrd Land: implications with regard to Southern Hemisphere tectonic reconstructions. In Gonzalez-Ferran, O., ed. Proceedings of the International Symposium on Andean and Antarctic Volcanology Problems. Rome, International Association of Volcanology and Chemistry of the Earth's Interior, 398-424.

Lipenkov, V.Ya., N.I. Barkov, P. Duval and P. Pimienta. 1989. Crystalline texture of the $2083 \mathrm{~m}$ ice core at Vostok Station, Antarctica. J. Glaciol., 35(121), 392-398.

Meese, D.A. and 8 others. 1997. The Greenland Ice Sheet Project 2 depth-age scale: methods and results. J. Geophys. Res., 102(C12), 26,411-26,423.

Narcisi, B., J.R. Petit, B. Delmonte, I. Basile-Doelsch and V. Maggi. 2005. Characteristics and sources of tephra layers in the EPICADome C ice record (East Antarctica): implications for past atmospheric circulation and ice core stratigraphic correlations. Earth Planet. Sci. Lett., 239(3-4), 253-265.

Nereson, N.A., E.D. Waddington, C.F. Raymond and H.P. Jacobson. 1996. Predicted age-depth scales for Siple Dome and inland WAIS ice cores in West Antarctica. Geophys. Res. Lett., 23(22), 3163-3166.

Nye, J.F. 1963. Correction factor for accumulation measured by the thickness of the annual layers in an ice sheet. J. Glaciol., 4(36), 785-788.

Palais, J.M. 1985a. Particle morphology, composition and associated ice chemistry of tephra layers in the Byrd ice core: evidence for hydrovolcanic eruptions. Ann. Glaciol., 7, 42-48.
Palais, J.M. 1985b. Tephra layers and ice chemistry in the Byrd Station ice core. (PhD thesis, Ohio State University.)

Palais, J.M., P.R. Kyle, W.C. McIntosh and D. Seward. 1988. Magmatic and phreatomagmatic volcanic activity at Mt. Takahe, West Antarctica, based on tephra layers in the Byrd ice core and field observations at Mt. Takahe. J. Volcan. Geotherm. Res., 35(4), 295-317.

Pettit, E.C. 2003. Unique dynamic behaviours of ice divides: Siple Dome and the rheological properties of ice. (PhD thesis, University of Washington.)

Rampino, M.R. 1993. Climate-volcanism feedback and the Toba eruption of $\sim 74,000$ years ago. Quat. Res., 40(3), 269-280.

Rigsby, G.P. 1955. Study of ice fabrics, Thule area, Greenland. SIPRE Rep. 26. 1-6.

Severinghaus, J.P., A. Grachev, B. Luz and N. Caillon. 2003. A method for precise measurement of argon 40/36 and krypton/ argon ratios in trapped air in polar ice with applications to past firn thickness and abrupt climate change in Greenland and at Siple Dome, Antarctica. Geochim. Cosmochim. Acta, 67(2), 325-343.

Song, M., D.M. Cole and I. Baker. 2005. Creep of granular ice with and without dispersed particles. J. Glaciol., 51(173), 210-218.

Swinzow, G.K. 1962. Investigation of shear zones in the ice sheet margin, Thule area, Greenland. J. Glaciol., 4(32), 215-229.

Taylor, K.C. and 13 others. 2004a. Abrupt climate change around 22 ka on the Siple Coast of Antarctica. Quat. Sci. Rev., 23(1-2), $7-15$.

Taylor, K.C. and 13 others. 2004b. Dating the Siple Dome (Antarctica) ice core by manual and computer interpretation of annual layering. J. Glaciol., 50(170), 453-461.

Thorsteinsson, T. 2002. Fabric development with nearest-neighbour interaction and dynamic recrystallization. J. Geophys. Res., 107(B1), 2014. (10.1019/2001JB000244.)

Wang, Y., S. Kipfstuhl, N. Azuma, T. Thorsteinsson and H. Miller 2003. Ice-fabrics study in the upper $1500 \mathrm{~m}$ of the Dome C (East Antarctica) deep ice core. Ann. Glaciol., 37, 97-104.

Whillans, I.M. 1979. Ice flow along the Byrd Station strain network, Antarctica. J. Glaciol., 24(90), 15-28.

Wilch, T.I., W.C. Mclntosh and N.W. Dunbar. 1999. Late Quaternary volcanic activity in Marie Byrd Land: potential ${ }^{40} \mathrm{Ar} /{ }^{39} \mathrm{Ar}-$ dated time horizons in West Antarctic ice and marine cores. Geol. Soc. Am. Bull., 111(10), 1563-1580. 